\title{
Planificación urbanística del turismo: la regulación de las viviendas de uso turístico en Madrid y Barcelona
}

\author{
Urban planning of tourism: regulation of touristic apartments \\ in Madrid and Barcelona
}

\author{
Alejandro Román Márquez \\ Universidad de Sevilla \\ aroman2@us.es
}

\begin{abstract}
NOTA BIOGRÁFICA
Alejandro Román Márquez es licenciado en Derecho (2004), Doctor (2009) -Universidad de Granada- y máster en Patrimonio Cultural y Natural (2012) -Universidad Internacional de Andalucía-. Es profesor del Departamento de Derecho Administrativo de la Universidad de Sevilla y miembro del Instituto Universitario de Investigación García Oviedo. Sus principales líneas de investigación son el Derecho del turismo y la contratación pública.
\end{abstract}

\section{RESUMEN}

Las importantes restricciones que el planeamiento urbano ha impuesto a las viviendas de uso turístico en las ciudades de Madrid y Barcelona imponen un examen de estas medidas desde el punto de vista de los principios de buena regulación económica, la libre prestación de servicios y la protección de los derechos fundamentales de ciudadanos en general y de propietarios de viviendas en particular.

\section{PALABRAS CLAVE}

Moratoria turística; planeamiento urbano; principios de buena regulación; viviendas de uso turístico.

\section{ABSTRACT}

The important restrictions that the urban planning has imposed on the touristic apartments in the cities of Madrid and Barcelona impose an examination of these measures from the point of view of the principles of good economic regulation, the free provision of services and the protection of the fundamental rights of citizens in general and owners of housing in particular.

\section{KEYWORDS}

Tourism moratorium; urban planning; principles of good regulation; touristic apartments.

\section{SUMARIO}

INTRODUCCIÓN. 1. LA REGULACIÓN DE LAS ACTIVIDADES DE ALOJAMIENTO TURÍSTICO A TRAVÉS DE LA PLANIFICACIÓN URBANÍSTICA: LOS PLANES URBANÍSTICOS ESPECIALES DE MADRID Y BARCELONA. 1.1. PERSPECTIVA GENERAL. 1.2. ALGUNAS CONSIDERACIONES SOBRE LA PLANIFICACIÓN URBANÍSTICA DEL ALOJAMIENTO TURÍSTICO DESDE LA PERSPECTIVA DE LA COMPETENCIA. 2. JUSTIFICACIÓN DE LAS RESTRICCIONES AL ESTABLECIMIENTO DE VIVIEN- 
REALA. Nueva Época - N. 10, Octubre 2018 - ISSN: 1989-8975 - DOI: 10.24965/reala.v0i10.10566 - [Págs. 22-39]

Planificación urbanística del turismo: la regulación de las viviendas de uso turístico en Madrid y Barcelona

Alejandro Román Márquez

DAS DE USO TURÍSTICO: LOS OBJETIVOS DE LA PLANIFICACIÓN URBANÍSTICA DE LOS USOS TURÍSTICOS. 3. RESTRICCIONES A LA EXPLOTACIÓN DE VIVIENDAS DE USO TURÍSTICO EN LAS CIUDADES DE BARCELONA Y MADRID. 3.1. RESTRICCIONES CONTENIDAS EN EL PLAN ESPECIAL URBANÍSTICO PARA LA REGULACIÓN DE LOS ESTABLECIMIENTOS DE ALOJAMIENTO TURISSTICO, ALBERGUES DE JUVENTUD, RESIDENCIAS COLECTIVAS DOCENTES DE ALOJAMIENTO TEMPORAL Y VIVIENDAS DE USO TURÍSTICO DE LA CIUDAD DE BARCELONA. 3.2. RESTRICCIONES CONTENIDAS EN EL PLAN ESPECIAL DE REGULACIÓN DEL USO DE SERVICIOS TERCIARIOS EN LA CLASE DE HOSPEDAJE DE MADRID. REFLEXIÓN FINAL: OBJETIVOS BIENINTENCIONADOS, DIAGNÓSTICO DEFICIENTE Y CONSECUENCIAS IMPREVISIBLES. REFERENCIAS BIBLIOGRÁFICAS.

\section{INTRODUCCIÓN}

El fenómeno de las viviendas particulares ofertadas por sus propietarios como alojamientos turísticos ha alcanzado en los últimos años una enorme relevancia, tanto en España o en otros países de su entorno. Las ciudades de Madrid y Barcelona han aprobado recientemente instrumentos de planificación urbanística con la finalidad de regular los usos turísticos del suelo, entre los que se incluyen, además de la oferta clásica de establecimientos de alojamiento turístico (hoteles, hoteles-apartamento, hostales, pensiones, etc.), las viviendas particulares de uso turístico. La regulación de una determinada actividad económica se ha justificado tradicionalmente por la existencia de fallos de mercado, siendo los más usuales la existencia de asimetrías informativas ${ }^{1}$ y de externalidades negativas ${ }^{2}$. La planificación urbanística de las viviendas de uso turístico en Madrid y Barcelona se ha enfocado principalmente a la eliminación de las segundas, identificadas con la saturación de determinados espacios y servicios públicos y con el alza de los precios de la vivienda en las áreas centrales de sendas ciudades. Partiendo de esta premisa, los Ayuntamientos de Madrid y Barcelona se han dotado de unas normas extremadamente restrictivas de la actividad turística de alojamiento, con consecuencias inmediatas en el mercado de las viviendas de uso turístico.

El artículo 129 de la Ley 39/2015, de 1 de octubre, del Procedimiento Administrativo Común de las Administraciones Públicas, que recoge el principio de buena regulación, dispone que, en el ejercicio de la iniciativa legislativa y la potestad reglamentaria, las Administraciones Públicas actuarán de acuerdo con los principios de necesidad, eficacia, proporcionalidad, seguridad jurídica, transparencia y eficiencia. En virtud de los principios de necesidad y eficacia, la iniciativa normativa debe estar justificada «[...] por una razón de interés general, basarse en una identificación clara de los fines perseguidos y ser el instrumento más adecuado para garantizar su consecución». En virtud del principio de proporcionalidad «[...] la iniciativa que se proponga deberá contener la regulación imprescindible para atender la necesidad a cubrir con la norma, tras constatar que no existen otras medidas menos restrictivas de derechos, o que impongan menos obligaciones a los destinatarios». Como recuerda Rodríguez Font (2017: 416), «[d]e todos estos principios el de necesidad, por su contenido, es del todo fundamental, pues su adecuada ponderación justifica la existencia de la norma en sí misma: si no hay razón de interés general, la intervención pública en forma de regulación queda deslegitimada».

Los organismos encargados de la defensa de la competencia (ACCO, 2014: 3; 2017: 5) recuerdan la obligación de realizar una evaluación del impacto competitivo de la intervención de las Administraciones públicas en la economía, análisis que debe estar basado en los principios de necesidad, proporcionalidad y mínima distorsión, así como en el resto de los principios de buena regulación eficiente y favorecedora de la competencia. La variable de competencia constituye para éstos un factor de decisión que no puede obviarse y que debe ser tenido en cuenta por los poderes públicos, puesto que la alteración de las condiciones de competencia en el mercado puede impactar en términos de cantidad, calidad y precios de la oferta y, por tanto, repercutir negativamente en el bienestar de los consumidores. Por esta razón, resulta

\footnotetext{
1 Existe asimetría informativa cuando las partes de una relación comercial no disponen de la misma cantidad de información sobre el producto o servicio objeto de transacción. En el ámbito turístico, el consumidor ha tenido tradicionalmente una menor cantidad de información que el oferente de los servicios debido a que, por su naturaleza, son generalmente contratados de forma anticipada y a distancia (v. gr. las vacaciones del año siguiente en el extranjero). La ordenación, mediante normas jurídicas, de los establecimientos de alojamiento turístico tiene como objetivo atenuar la asimetría informativa que afecta a los turistas, fijando estándares obligatorios de calidad y servicios que puedan ser conocidos fehacientemente por éstos.

2 Las externalidades negativas son los costes o daños generados por una actividad que no se repercuten en su precio. Es decir, las externalidades negativas son los efectos adversos de determinadas actividades que son disfrutadas por los consumidores sin que éstos compensen económicamente a los perjudicados por ella ( $v$. gr. la contaminación atmosférica generada por determinadas actividades industriales).
} 
REALA. Nueva Época - N. 10, Octubre 2018 - ISSN: 1989-8975 - DOI: 10.24965/reala.v0i10.10566 - [Págs. 22-39]

Planificación urbanística del turismo: la regulación de las viviendas de uso turístico en Madrid y Barcelona

Alejandro Román Márquez

imprescindible que los poderes públicos ponderen los diferentes intereses en juego, contraponiendo los beneficios asociados a la introducción de una restricción con los costes que implica en términos de menor competencia. En ausencia de este examen es posible que las restricciones generen innecesarios e injustificados costes en materia de competencia y prosperidad ciudadana, además de algunos problemas de legalidad.

La Comisión Nacional del Mercado y de las Comunicaciones (CNMC) publicó en el mes de julio de 2018 el Estudio sobre la regulación de las viviendas de uso turístico en España, que viene a actualizar las apreciaciones que sobre esta materia contenía el controvertido Estudio sobre los nuevos modelos de prestación de servicios y economía colaborativa -resultados preliminares- de $2016^{3}$. En las mismas fechas se anunció el recurso contra la normativa urbanística municipal de viviendas turísticas de Madrid, Bilbao y San Sebastián, por considerar que resulta contraria con los principios de regulación económica eficiente, y después de que los Ayuntamientos afectados no contestasen a satisfacción de la CNMC sendos requerimientos previos para que justificasen la necesidad y proporcionalidad de estas medidas restrictivas 0 , alternativamente, procediesen a su anulación (CNMC, 2018b).

En las páginas siguientes se analiza el marco jurídico que las ciudades de Madrid y Barcelona han impuesto a las viviendas de uso turístico desde una perspectiva espacial a través de sendos planes urbanísticos especiales. Este examen evalúa la oportunidad de utilizar instrumentos de planeamiento urbanístico como medio para ordenar determinadas actividades económicas, la justificación de las medidas adoptadas por los Ayuntamientos de Madrid y Barcelona y su encaje con los principios de necesidad y proporcionalidad, así como la congruencia entre ambos principios y las medidas finalmente aprobadas.

\section{LA REGULACIÓN DE LAS ACTIVIDADES DE ALOJAMIENTO TURÍSTICO A TRAVÉS DE LA PLANIFICACIÓN URBANÍSTICA: LOS PLANES URBANÍSTICOS ESPECIALES DE MADRID Y BARCELONA}

\subsection{Perspectiva general}

El Ayuntamiento de Barcelona aprobó definitivamente, en su sesión plenaria del 27 de enero de 2017, el Plan Especial Urbanístico para la regulación de los establecimientos de alojamiento turístico, albergues de juventud, residencias colectivas docentes de alojamiento temporal y viviendas de uso turístico de la Ciudad de Barcelona (en adelante, PEUAT) ${ }^{4}$. Este instrumento de planificación, que deroga el preexistente Plan Especial Urbanístico para la regulación de las Viviendas de Uso Turístico de $2016^{5}$, tiene como finalidad la regulación de los usos del suelo en el término municipal de Barcelona respecto de determinados establecimientos de alojamiento temporal y turístico, entre los que se incluyen las viviendas de uso turístico. Con relación a estas últimas, el PEUAT se remite en bloque al Decreto catalán 159/2012, de 20 de noviembre, de establecimientos de alojamientos de uso turístico y de viviendas de uso turístico, para localizar su régimen jurídico. En la Comunidad Autónoma catalana se consideran viviendas de uso turístico aquéllas que sean cedidas por su propietario, directa o indirectamente, a terceros y a cambio de contraprestación económica, para una estancia de temporada, en condiciones de inmediata disponibilidad y con las características establecidas en el citado Decreto. El resto de fuentes que contienen el régimen jurídico de las viviendas de uso turístico en Cataluña son las siguientes: la normativa sectorial o municipal que resulte de aplicación y la Ordenanza municipal que, en su caso, regule este tipo de establecimientos ${ }^{6}$.

\footnotetext{
${ }^{3}$ En este estudio se apostó por no regular esta actividad si se llegase a la conclusión de que no existen fallos de mercado, siendo precisamente la ausencia de regulación la respuesta más eficiente al fenómeno de las viviendas de uso turístico (CNMC, 2016: 9). En este sentido advierte RODRÍGUEZ FONT (2017: 416) que la iniciativa normativa debe constituir la mejor opción para cumplir con los principios de buena regulación, puesto que en el contexto de la economía colaborativa la regulación no es, tal y como ha señalado la CNMC, la única opción posible para encauzar sus efectos y potencialidades. En contra de este abstencionismo regulatorio se encuentran autores como ROCA FERNÁNDEZ-CASTANYS (2017: 4), para quien el volumen económico de esta actividad legitima la intervención y el control administrativo, por lo que su «atención normativa» estaría plenamente justificada, pero siempre a través fórmulas ponderadas que eviten regulaciones innecesarias y desproporcionadas que perjudiquen a los consumidores, al interés general y a la competencia efectiva.

${ }^{4}$ Boletín Oficial de la Provincia de Barcelona de 6 de marzo de 2017.

${ }^{5}$ Aprobado definitivamente por el Pleno del Consejo Municipal de Barcelona el 1 de abril de 2016, Boletín Oficial de la Provincia de Barcelona de 21 de abril de 2016.

${ }^{6}$ Artículos 8.2, 21 y 22.1.a PEUAT.
} 
REALA. Nueva Época - N. 10, Octubre 2018 - ISSN: 1989-8975 - DOI: 10.24965/reala.v0i10.10566 - [Págs. 22-39]

Planificación urbanística del turismo: la regulación de las viviendas de uso turístico en Madrid y Barcelona

Alejandro Román Márquez

EI PEUAT regula de forma específica las condiciones urbanísticas de emplazamiento de las viviendas de uso turístico en función de la delimitación espacial de su ámbito de aplicación. Para ello, se establecen una serie de áreas territoriales -denominadas Zonas Específicas- delimitadas conforme a su «sensibilidad» para acoger nuevas viviendas de uso turístico en atención a la intensidad de la oferta actual de alojamientos turísticos, la relación de plazas ofertadas respecto de la población residente, la saturación del espacio público y la morfología urbana o la especialización urbanística preponderante en la zona. En cada una de estas áreas se establecen unos requisitos diferenciados para la implantación de nuevas viviendas de uso turístico, llegando a prohibirse completamente en alguna de ellas.

Como elemento fundamental del sistema instaurado por el PEUAT, éste crea el censo de establecimientos de alojamiento turístico, albergues de juventud, residencias colectivas docentes de alojamiento temporal y viviendas de uso turístico (CEAT), al cual se deben incorporar todas las viviendas de uso turístico autorizadas, con el objetivo de conocer en cada momento su número exacto. Cualquier solicitud de autorización de una nueva vivienda de uso turístico requerirá la constatación previa de que, conforme a los datos obrantes en el CEAT, aquélla resulta compatible con la capacidad de crecimiento de la oferta turística prevista en el PEUAT ${ }^{7}$.

Por su parte, el Ayuntamiento de Madrid aprobó inicialmente, en el mes de julio de 2018 , el Plan Especial de Regulación del Uso de Servicios Terciarios en la clase de Hospedaje (en adelante, PERUH). Este plan de regula los usos compatibles y autorizables del hospedaje turístico en edificios destinados a viviendas en una amplia porción del término municipal de la Ciudad de Madrid, con el objetivo manifiesto de preservar el uso residencial del centro urbano y, de forma añadida, extender la actividad de alojamiento turístico a otras zonas de la ciudad, redistribuyendo la actividad económica y descargando la concentración del centro histórico. EI PERUH subordina la posibilidad de explotación de viviendas particulares como alojamiento turístico a tres condicionantes: a) la profesionalidad de la actividad, b) su ubicación y, c) la preexistencia de uso terciario. En relación con el primero de los condicionantes, se fija un umbral de tres meses relativos a la oferta de alojamiento turístico en aquellas viviendas que constituyan residencia permanente, por debajo del cual quedan excepcionadas de la aplicación del plan, al no ser considerada aquélla como actividad empresarial de hospedaje turístico por la normativa autonómica madrileña. En relación con el segundo de los condicionantes señalados, el PERUH delimita tres sectores en forma de anillos concéntricos, establecidos en función del estado de saturación de alojamientos turísticos que soportan cada uno de los barrios madrileños. $Y$ en relación con el tercero y último de ellos, se flexibiliza el acceso a la actividad de alojamiento turístico para aquellas viviendas ubicadas en edificios pertenecientes al tercer anillo en los que se admitan otros usos terciarios, como oficinas o comercios.

En ambas ciudades el sistema elegido de planificación urbanística de las viviendas de uso turístico responde al modelo tradicional de regulación detallada de usos del suelo-zonificación-, que generalmente presenta el siguiente patrón (ACCO, 2014: 4): en primer lugar se definen las diferentes tipologías de actividades, de forma que quien pretenda iniciar una concreta actividad pueda saber en qué tipología se encuadra la que resulte de su interés, y, adicionalmente, se divide el ámbito territorial de aplicación del instrumento de

7 La inscripción en este registro público no se configura como un requisito previo para el inicio de la actividad de alojamiento. La CNMC (2018a: 41) advierte de que la tripe exigencia contenida en numerosas normas autonómicas, consistente en la obligación conjunta de presentar declaración responsable y realizar la inscripción en un registro, condicionando el inicio de la actividad a la confirmación por la Administración de la inscripción en tal registro, "anula el objetivo inherente a la declaración responsable, consistente en no obstaculizar el desarrollo de la actividad y dinamizar el mercado, convirtiéndola de facto en una autorización administrativa». A este respecto, debe recordarse cómo la sentencia del Tribunal Superior de Justicia de Canarias núm. 41/2017, de 21 de marzo, anuló el artículo 13.3 del Decreto 113/2015, de 22 de mayo, por el que se aprueba el Reglamento de las viviendas vacacionales de la Comunidad Autónoma de Canarias, que condicionaba la obtención de las hojas de reclamaciones, el cartel anunciador de las mismas y el libro de inspección -requisitos necesarios para la explotación turística de la vivienda- a su inscripción efectiva en el Registro General Turístico de la Comunidad Autónoma de Canarias de Canarias (para lo cual el Cabildo Insular gozaba de un plazo de quince días desde hábiles desde la fecha de presentación de la declaración responsable de inicio de actividad por parte del titular o explotador de la vivienda). Tal y como advierte este pronunciamiento, debe reputarse contrario al ordenamiento jurídico cualquier mecanismo que prive a la declaración responsable de la virtualidad de habilitar el comienzo de la actividad desde el mismo día de su presentación, en atención a la configuración de este instrumento de control regulado por el artículo 69.3 de la Ley 39/2015, de 1 de octubre, del Procedimiento Administrativo Común de las Administraciones Públicas. En el caso canario, «[c]omo el inicio de la actividad sin la referida documentación es motivo de sanción, de facto esta regulación está desnaturalizando los efectos de la declaración responsable y sometiendo el inicio de la actividad a un control administrativo previo» (Fundamento de derecho séptimo). En el mismo sentido CCA (2014), ACCO (2015) y AVC (s/f). Para un análisis de la normativa autonómica en esta materia vid. DE LA ENCARNACIÓN (2016) y ROMÁN SÁNCHEZ et al. (2017).

${ }^{8}$ Acuerdo de la Junta de Gobierno de la Ciudad de Madrid de 26 de julio de 2018, Boletín Oficial de la Comunidad de Madrid núm. 196, de 17 de agosto de 2018, pág. 63. 
REALA. Nueva Época - N. 10, Octubre 2018 - ISSN: 1989-8975 - DOI: 10.24965/reala.v0i10.10566 - [Págs. 22-39]

Planificación urbanística del turismo: la regulación de las viviendas de uso turístico en Madrid y Barcelona

Alejandro Román Márquez

planeamiento ( $v$. gr. un término municipal) en diversas zonas determinadas administrativamente. Con base en ambos parámetros -tipología de actividades y áreas predeterminadas- se regula la presencia de cada una de las actividades en las diferentes zonas. Se trata, desde la perspectiva turística, del establecimiento de reglas urbanísticas de incompatibilidad horizontal de usos (Doménech Pascual, 2018: 57), en virtud de las cuáles se prohíbe o limita el uso turístico de las viviendas particulares en determinadas áreas del término municipal ${ }^{9}$.

Como medida complementaria a la tramitación de estos planes los Ayuntamientos de Madrid y Barcelona han aprobado sendas moratorias ${ }^{10}$ que afectan a los establecimientos de alojamiento turístico, incluyendo las viviendas de uso turístico, por lo que la tramitación y concesión de licencias turísticas ha quedado suspendida, al menos, durante un año desde la aprobación definitiva de PEUAT y PERUH.

\subsection{Algunas consideraciones sobre la planificación urbanística del alojamiento turístico desde la perspectiva de la competencia}

Para realizar un correcto análisis de la planificación urbanística de las viviendas de uso turístico desde la perspectiva de la promoción de la competencia resulta ineludible establecer su régimen jurídico, lo cual pasa inevitablemente por determinar si la regulación de los usos turísticos del suelo está sometida o no a la Directiva de Servicios y a la normativa interna de transposición. La Directiva 2006/123/CE, de 12 de diciembre de 2006, relativa a los servicios en el mercado interior, excluye de su ámbito de aplicación a aquellos requisitos que afecten al acceso a una actividad de servicios o a su ejercicio en materia de urbanismo (Considerando núm. 9). Esta exclusión genera, por tanto, una duda legítima en torno a la cuestión de si la Directiva de Servicios, con todas sus restricciones y cautelas al establecimiento de barreras de entrada de nuevos competidores en el mercado, resulta de aplicación a la planificación urbanística de las viviendas de uso turístico. Los organismos encargados de la defensa de la competencia se han pronunciado en varios documentos sobre esta cuestión, manteniendo una posición favorable a la aplicación de la Directiva de Servicios a la planificación urbanística de las viviendas de uso turístico (CNMC, 2018a: 48; ACCO, 2014: 19, 2017: 6). Consideran éstos que una regulación de los usos del suelo que contenga requisitos para el establecimiento de actividades turísticas posee naturaleza eminentemente económica o comercial, a pesar de estar contenidos en un instrumento urbanístico, por lo que resulta plenamente aplicable la Directiva de Servicios. En consecuencia, la planificación urbanística de las viviendas de uso turístico debe respetar los principios que regulan el establecimiento de requisitos para el acceso de una actividad de servicios o su ejercicio: necesidad y proporcionalidad ${ }^{11}$.

A favor de esta interpretación estaría la sentencia del Tribunal de Justicia la Unión Europea de 24 de marzo de 2011 (Comisión Europea vs Reino de España, asunto C-400/08), que consideró que la regulación catalana sobre grandes establecimientos comerciales presentaba carácter económico, así como la sentencia del Tribunal Superior de Justicia de Cataluña núm. 613/2013, de 30 de septiembre, que, fundamentada en la anterior, anuló determinados preceptos del Plan especial de equipamiento comercial alimenticio de Barcelona. En contra, la sentencia del Tribunal Superior de Justicia de Cataluña núm. 199/2014, de 2 de

\footnotetext{
9 Por el contrario, las reglas de incompatibilidad vertical limitan las posibilidades de que en un mismo edificio coexistan los usos residencial y turístico. V. gr. la Ley 8/2012, de 19 de julio, del Turismo de las Islas Baleares (modificada posteriormente por la Ley 6/2017), restringió la localización de viviendas de uso turístico a las viviendas unifamiliares aisladas o pareadas, excluyendo, por tanto, la posibilidad de que aquéllas se ubicasen en edificios sometidos a régimen de propiedad horizontal y compartiesen espacio con viviendas destinadas a residencia habitual.

10 En Barcelona la primera de sus moratorias data de 2010 y afectó al Distrito de Ciudad Vella, ampliándose al resto de la ciudad en 2015 (Acuerdo de la Comisión de Gobierno del Ayuntamiento de Barcelona de 1 de julio, Boletín Oficial de la Provincia de Barcelona de 2 de julio). El Plan Especial Urbanístico para la regulación de las Viviendas de Uso Turístico de 2016 y el actual PEUAT han continuado la suspensión. En Madrid, la primera moratoria turística se acordó el 1 de febrero de 2018 (Boletín Oficial de la Comunidad de Madrid núm. 30, de 5 de febrero, pág. 104), siendo ésta objeto de recurso por la CNMC. El PERUH propone la prórroga de la actual moratoria por espacio de un año, ampliable por otro más.

11 La ACCO sostiene su posición basándose, principalmente, en lo señalado por la Unión Europea en su Manual sobre la Transposición de la Directiva de Servicios: «[...] el simple hecho de que se atribuya a tales normas la denominación específica, por ejemplo, como normas urbanísticas [...] no es suficiente para excluirlas del ámbito de la Directiva de servicios. [L]os Estados miembros tendrán que tener en cuenta que las "normas urbanísticas" o las "ordenanzas de construcción" pueden contener requisitos que regulan de manera específica actividades de servicios y que, por lo tanto, están cubiertos por la Directiva de Servicios. Por ejemplo, las disposiciones sobre la superficie máxima de ciertos establecimientos comerciales, aunque figuren en las normas urbanísticas generales, están comprendidas en el ámbito de aplicación de la Directiva de Servicios y, en consecuencia, tienen que atenerse a aquello previsto en el capítulo sobre la libertad de establecimiento de ésta» (VV.AA, 2007: 15).
} 
REALA. Nueva Época - N. 10, Octubre 2018 - ISSN: 1989-8975 - DOI: 10.24965/reala.v0i10.10566 - [Págs. 22-39]

Planificación urbanística del turismo: la regulación de las viviendas de uso turístico en Madrid y Barcelona

Alejandro Román Márquez

abril, que enjuicia la adecuación a derecho del Plan especial de establecimientos de concurrencia pública, hostelería y otros servicios del Distrito de Ciutat Vella (Barcelona). Esta sentencia declara nula la exigencia de renuncia previa de una o varias licencias de actividad titularidad del mismo solicitante para obtener una nueva, pero considera que el resto de las restricciones contenidas en el plan no son contrarias a la Directiva de servicios por estar recogidas en una norma urbanística ${ }^{12}$.

Si bien tampoco existe unanimidad en la doctrina en torno a esta cuestión ${ }^{13}$, en mi opinión parece claro que este tipo de planes no responden a la finalidad propia de la planificación urbana, cual es la ordenación arquitectónica de los espacios de la ciudad y las condiciones para su transformación y desarrollo, sino que contiene importantes implicaciones económicas que trascienden a la materia urbanística. La única finalidad de estos planes es regular una determinada actividad económica, por lo que su naturaleza como instrumento urbanístico debe ser puesto en entredicho a los efectos de su exclusión de la Directiva de Servicios, por más que su existencia pueda estar justificada para sus redactores en razones como la supuesta incompatibilidad relativa a los usos del suelo entre la actividad de alojamiento turístico y el uso residencial de las viviendas, o en la protección del derecho fundamental a una vivienda digna.

Se reconocen algunos efectos positivos a la técnica de la zonificación desde la perspectiva de la competencia (CNMC, 2018a: 50 a 53; ACCO, 2014: 9 a 11), como el aumento de la rivalidad competitiva de los operadores - puesto que, debido a la concentración en determinadas zonas, éstos están situados más cerca unos de otros ${ }^{14}$ - y la disminución de los costes de investigación de los consumidores -que pueden comparar precios y servicios más fácilmente-. Sin embargo, sus efectos negativos son muy relevantes. Si el suelo, considerado en términos generales como un recurso limitado, es objeto de una regulación detallada y restrictiva respecto de sus usos se dificulta e, incluso, se puede llegar a impedir el establecimiento de nuevos operadores en el mercado. Las barreras de entrada absolutas o insalvables (v. gr. moratorias turísticas) generan unos costes para la competencia de forma directa, al impedir la aparición de nuevos competidores en el mercado y, por tanto, limitando la oferta del mercado y provocando su cierre. Las barreras de entrada relativas o salvables ( $v$. gr. numerus clausus de establecimientos o plazas turísticas, requisitos relativos a dimensiones mínimas, equipamiento o seguridad, etc.) dificultan la entrada de nuevos competidores en el mercado, al implicar un incremento de los costes en términos económicos y de tiempo para los potenciales nuevos competidores, los cuáles ven reducida su capacidad para competir con los operadores preexistentes -incumbentes- como consecuencia de la obligación de asumir tales sobrecostes -costes regulatorios-. Adicionalmente, se produce un efecto desincentivador para los potenciales nuevos competidores, que ven reducidos los estímulos para entrar en el mercado. Se trata, en definitiva, de una auténtica «regulación disuasoria», cuya finalidad última no es ordenar la actividad, sino desincentivar la entrada en el mercado de nuevos operadores.

La ordenación de la actividad de las viviendas de uso turístico en función de determinadas zonas predeterminadas administrativamente genera, además, barreras geográficas dentro de los mercados, tanto regionales como locales, que redunda una vez más en perjuicio de los consumidores y usuarios; y su restricción a determinadas zonas elimina las denominadas «economías de aglomeración», generadas por la existencia de infraestructuras compartidas y externalidades de información acerca de la localización de la oferta, las cuales contribuyen a reducir los costes de búsqueda de los consumidores y generar externalidades positivas sobre otros establecimientos (CNMC 2018a: 50, 51).

Desde el punto de vista de los operadores ya instalados en el mercado, las barreras de entrada absolutas o relativas a los nuevos operadores generan igualmente una serie de efectos negativos: reduce las presiones competitivas que sienten los operadores incumbentes por la potencial entrada de nuevos operadores en el mercado, lo que reduce los estímulos para mejorar la calidad y competitividad de la oferta existente,

12 Esta sentencia ha sido recurrida en casación ante el Tribunal Supremo. En idéntico sentido, la sentencia del Tribunal Superior de Justicia de Cataluña núm. 357/2014, de 12 de junio.

${ }_{13}$ Así, v. gr., SOCIAS CAMACHO (2018: 152) considera que para dilucidar esta cuestión resulta necesario diferenciar dos situaciones: a) una, relacionada con el ámbito del urbanismo o la ordenación del territorio, y en que estaría excluida la aplicación de la Directiva de Servicios, al incidir sobre la implantación urbanística de las viviendas que pueden destinarse al uso turístico, determinado ciertas condiciones «previas» o «colaterales» al ejercicio de la comercialización turística de las viviendas, del mismo modo que el planeamiento urbanístico regula otros aspectos por la vía de la fijación de estándares u otros procedimientos; y b) otra, relacionada con la actividad y las condiciones de prestación del servicio, es decir, la actividad concreta y específica a desarrollar y sus condiciones de funcionamiento posterior, sometida a la Directiva de Servicios y legislación de transposición.

${ }_{14} \mathrm{Si}$ bien la tendencia natural del comercio es la concentración espacial en determinadas calles o áreas de la ciudad para aprovechar las diferentes sinergias que genera su proximidad. 
REALA. Nueva Época - N. 10, Octubre 2018 - ISSN: 1989-8975 - DOI: 10.24965/reala.v0i10.10566 - [Págs. 22-39]

Planificación urbanística del turismo: la regulación de las viviendas de uso turístico en Madrid y Barcelona

Alejandro Román Márquez

pues no perciben en la misma medida la necesidad en mejorar o diferenciar su producto $(v$. gr. ofreciendo mejores servicios o condiciones que sus competidores); se incrementa el precio de los traspasos de negocios, debido a la escasez total o relativa de permisos de entrada al mercado ${ }^{15}$, lo que beneficia directamente a los operadores establecidos como consecuencia de una decisión administrativa ajena a los mecanismos de conformación de la oferta y la demanda -rentas regulatorias o monopolísticas-; y se aumenta la probabilidad de comportamientos colusorios, puesto que los operadores tienen un conocimiento profundo y estable de la competencia, que no se altera cuantitativamente a lo largo del tiempo (o lo hace muy poco). Todo ello supone conceder a los operadores preexistentes a la implantación de barreras de entrada al mercado una situación de privilegio frente a los potenciales nuevos competidores que no está justificada en términos de méritos empresariales ( $v$. gr. como consecuencia de su mayor eficiencia, adaptación a las preferencias de la demanda o política de precios), sino por la intervención de la Administración pública en el mercado.

En definitiva, la regulación restrictiva de los usos del suelo provoca un impacto negativo en la competencia $y$, por ende, en el bienestar del consumidor, puesto que reduce la variedad, cantidad y calidad de la oferta, disminuye los estímulos a la innovación empresarial y provoca un aumento generalizado de precios ${ }^{16}$. En este sentido, la CNMC (2018a: 48,51) considera que determinar mediante el planeamiento urbanístico dónde puede establecerse una vivienda de uso turístico o cuál es el número ideal de estas viviendas en un área determinada carece de justificación desde el punto de vista económico. Recuerda este organismo que «[e]n el mercado del suelo, pueden existir determinados tipos de fallos de mercado, generalmente vinculados a externalidades por usos incompatibles del suelo, que conduzcan a un tamaño excesivo de una ciudad, o a la provisión de bienes públicos. Es decir, la zonificación por usos propia del planeamiento español estaría vinculada a la existencia de una externalidad por uso incompatible, que tendría lugar si, por ejemplo, una fábrica que emite contaminación se instala al lado de un parque muy concurrido. Como consecuencia del efecto que dicho nivel de contaminación puede producir en la población cercana, tradicionalmente se ha considerado que está justificado mantener una cierta distancia entre la actividad contaminante y las zonas residenciales. Sin embargo, cabe señalar que una vivienda de uso turístico es un alojamiento destinado a un uso residencial, sin perjuicio de que la vivienda, o una parte de ella, pueda ser objeto de una cesión temporal. Por tanto, por su propia naturaleza, la cesión de viviendas de uso turístico debe ser compatible con el uso residencial de la vivienda».

Como alternativa a la zonificación, la CNMC (2015: 27; 2018a: 48, 52) propone mecanismos «más proporcionados», que pueden ser tanto mecanismos de mercado, en el que los propios individuos negocian para corregir las externalidades negativas existentes, como mecanismos de tipo normativo, pero que estén basados en estándares y no en la determinación del lugar concreto en el que deben localizarse ciertas actividades económicas. Otro de los mecanismos por lo que apuesta decididamente la CNMC es el establecimiento de «impuestos pigouvianos» ${ }^{17}$ a la actividad turística, los cuales permiten resolver el problema de las externalidades en origen. Como señala Rodríguez Font (2017: 418), los impuestos son los principales instrumentos públicos para internalizar, con carácter general, las externalidades negativas de los mercados, puesto que cuando éstos producen más cantidad de bienes o servicios de lo que resulta socialmente deseable, los gravámenes económicos son una medida efectiva para disminuir su cuantía hasta niveles óptimos. El establecimiento de impuestos a las estancias turísticas con el objetivo de desincentivar la demanda es una medida considerada igualmente por los redactores del PEUAT (Memoria, pág. 10), pero como medida complementaria a la planificación urbanística de las viviendas de uso turístico, no como alternativa a ésta. Actualmente, Ley 5/2017, de 28 de marzo, de medidas fiscales, administrativas, financieras y del sector público y de creación y regulación de los impuestos sobre grandes establecimientos comerciales, sobre estancias en establecimientos turísticos, sobre elementos radiotóxicos, sobre bebidas azucaradas envasadas y sobre emisiones de dióxido de carbono ${ }^{18}$, impone un pago de 2,25€ por pernocta en viviendas de

15 Ante la imposibilidad de acceder al mercado por otras vías, la única opción consiste en la adquisición de un permiso titularidad de otro operador, cuyo valor no responde a la dinámica del mercado sino a una decisión política que altera el libre juego de éste y le dota de su valor de transacción (ACCO, 2017: 9). 2018b).

16 El ingreso por habitación disponible -RevPAR- aumentó un 9,3\% en la ciudad de Barcelona durante el año 2017 (VV.AA,

17 Los impuestos pigouvianos son aquéllos que persiguen corregir una externalidad negativa ( $v$. gr. la contaminación atmosférica). Un ejemplo de impuesto pigouviano aplicado al turismo en España es el impuesto sobre estancias turísticas existente en la Comunidad Autónoma Balear -conocida como «ecotasa balear»-, regulado por el Decreto 35/2016, de 23 de junio, por el que se desarrolla la Ley del impuesto sobre estancias turísticas y de medidas de impulso del turismo sostenible.

18 Desarrollada por el Decreto 141/2017, de 19 de septiembre, por el que se aprueba el Reglamento del impuesto sobre las estancias en establecimientos turísticos. 
REALA. Nueva Época - N.o 10, Octubre 2018 - ISSN: 1989-8975 - DOI: 10.24965/reala.v0i10.10566 - [Págs. 22-39]

Planificación urbanística del turismo: la regulación de las viviendas de uso turístico en Madrid y Barcelona

Alejandro Román Márquez

uso turístico ubicadas en la ciudad de Barcelona y de 0,90€ por pernocta en las localizadas en el resto de Cataluña (art. 34.1).

Sin embargo, el uso de impuestos pigouvianos como mecanismo para redimensionar la demanda de viviendas de uso turístico también presenta inconvenientes (Doménech Pascual, 2018: 65). En primer lugar, porque no resulta fácil determinar la magnitud de las externalidades que el impuesto trata gravar y, por ende, su cuantía óptima, lo que puede provocar que ésta sea demasiado elevada o excesivamente baja, generando un nivel de turismo que no es el óptimo para la sociedad. En segundo lugar, su gestión y cobro puede generar costes relevantes (si bien reducibles mediante el uso de nuevas tecnologías). Y, en tercer lugar, la magnitud de las externalidades puede variar en función de las características, localización y acumulación de las viviendas de uso turístico, haciendo extremadamente dificultoso la integración de todas estas variables en el cálculo de la tasa. En cualquier caso, considero que este mecanismo es más respetuoso con el derecho constitucional a la libertad de empresa y protege mejor los intereses de los ciudadanos como consumidores que las restricciones, absolutas o relativas, a la explotación de las viviendas particulares como alojamientos de uso turístico en función de su localización geográfica.

Estos son, de forma sintética, los mecanismos que la CNMC propone como alternativa a la zonificación urbanística de los usos turísticos. En cualquier caso, este organismo advierte de que, para salvaguardar el principio de igualdad y realizar una correcta distribución de cargas, tales mecanismos deben aplicarse a todos los agentes que contribuyen a la congestión del medio urbano, es decir, a todas las modalidades de establecimientos de alojamiento turístico, y no de forma exclusiva a una determinada categoría de operadores, como sería el caso de las viviendas particulares de uso turístico.

\section{JUSTIFICACIÓN DE LAS RESTRICCIONES AL ESTABLECIMIENTO DE VIVIENDAS DE USO TURÍSTICO: LOS OBJETIVOS DE LA PLANIFICACIÓN URBANÍSTICA DE LOS USOS TURÍSTICOS}

Los instrumentos de planificación urbanística de las viviendas de uso turístico en las ciudades de Madrid y Barcelona coinciden en sus objetivos fundamentales, los cuales sirven de justificación a las restricciones impuestas para su establecimiento y explotación. Los diferentes objetivos fijados por los redactores de ambos planes pueden concretarse en los siguientes: a) uso equilibrado del suelo, b) reducción de externalidades negativas, y c) promoción del derecho a una vivienda digna.

En relación con el primero de estos objetivos, la tradicional flexibilidad de la ordenación urbanística de la ciudad ha propiciado una diversidad de los usos del suelo, la cual se encontraría amenazada por el intenso desarrollo turístico, que amenaza con implantar un monocultivo económico en torno a esta actividad. Algunos autores (Socias Camacho, 2017: 24) advierten de fenómenos como la urbanalización -homogeneización del paisaje urbano- o la brandificación-desaparición del comercio local y del patrimonio cultural en favor de las empresas transnacionales-, ambos vinculados con la actividad turística en los centros urbanos. Tales amenazas justificarían una intervención pública tan intensa en el mercado, alterando la ley de la oferta y la demanda. Este objetivo estaría conectado directamente con el principio de desarrollo territorial urbano y sostenible contenido en el artículo 3 del Real Decreto Legislativo 7/2015, de 30 de octubre, por el que se aprueba el texto refundido de la Ley de Suelo y Rehabilitación Urbana. En virtud de este principio, los poderes públicos deben formular y desarrollar las políticas de su respectiva competencia de acuerdo con los principios de competitividad y sostenibilidad económica, social y medioambiental, cohesión territorial, eficiencia energética y complejidad funcional, procurando que el suelo se ocupe de manera eficiente, combinando los usos de forma racional. Concretamente, en relación al objetivo del uso equilibrado del suelo en un contexto de alta presión turística, el número 3 de este precepto -apartados a, g y j- exige a los poderes públicos que posibiliten el uso residencial en viviendas constitutivas de domicilio habitual en un contexto urbano «integrado socialmente», así como la integración en el tejido urbano de cuantos usos resulten compatibles con la función residencial con el objetivo de contribuir al equilibrio de las ciudades y de los núcleos residenciales, favoreciendo la diversidad de usos, la aproximación a los servicios, dotaciones y equipamientos a la comunidad residente, así como la cohesión e integración social, y todo ello teniendo en cuenta la «perspectiva turística», en el sentido de facilitar el «uso turístico responsable».

Los organismos encargados de la defensa de la libre competencia han criticado la pretensión de equilibrar artificialmente los usos del suelo. Para la ACCO $(2014: 14,15,17)$ el error estaría en la pretensión misma de definir un concepto de uso equilibrado del suelo. Advierte este organismo sobre la enorme dificultad 
REALA. Nueva Época - N. 10, Octubre 2018 - ISSN: 1989-8975 - DOI: 10.24965/reala.v0i10.10566 - [Págs. 22-39]

Planificación urbanística del turismo: la regulación de las viviendas de uso turístico en Madrid y Barcelona

Alejandro Román Márquez

de determinar correctamente qué deba entenderse por oferta comercial «ideal» o «equilibrada», y para ello se vale del siguiente ejemplo: la planificación urbanística de las viviendas turísticas parte de una regulación de los usos del suelo que toma en consideración únicamente la oferta comercial física, sin tener en cuenta los importantes cambios que las nuevas tecnologías han operado en este ámbito como consecuencia del desarrollo y generalización del comercio electrónico. La existencia de un establecimiento físico próximo ha perdido relevancia para el aprovisionamiento de bienes y servicios de los habitantes de un determinado lugar. Sin embargo, en ningún caso puede afirmarse que el comercio electrónico haya convertido en irrelevante el elemento físico. Antes, al contrario, para la ACCO la ubicación física de los operadores sigue constituyendo un factor de competencia importante a la hora de desarrollar actividades económicas, y precisamente por ello considera que las restricciones en el establecimiento físico comportan un grave problema para la competencia precisamente porque constituyen un factor relevante para la potencial entrada al mercado de nuevos ofertantes de bienes y servicios ${ }^{19}$. Pero, desde el punto de vista inverso, «[...] la importancia del comercio electrónico y las mejoras en la distribución constituyen una realidad que no se puede desatender en la regulación de los usos del suelo que tenga como objetivo garantizar la diversidad comercial, ya que la oferta accesible a través de internet también forma parte de la oferta comercial total existente. [...] en coherencia, esta consideración debilita la justificación de las restricciones en los usos del suelo, de manera tal que es cuestionable que el objetivo perseguido continúe siendo necesario en el escenario actual y, incluso [sic] vista la previsible evolución - lo sea en menor medida en el futuro». Frente a los mecanismos restrictivos de la oferta propuestos por la planificación urbanística de Madrid y Barcelona, la ACCO propone incidir en el fomento de la demanda con medidas que logren un objetivo similar en la distribución espacial del comercio: promoción comercial que aumente la vitalidad de una determinada zona ( $v$. gr. actividades en la vía pública), mejora de la accesibilidad ( $v$. gr. peatonalización, zonas verdes como polos de atracción o aparcamiento gratuito) y asesoramiento, ayuda y estímulo a la reconversión de operadores comerciales ( $v$. gr. comercios tradicionales) $)^{20}$.

El segundo de los objetivos generales perseguidos por la planificación urbanística de las viviendas de uso turístico reúne, bajo el paraguas de la lucha contra las externalidades negativas vinculadas al fenómeno turístico, la atenuación de dos efectos adversos sobre la población residente: la degradación del espacio urbano y los problemas de convivencia entre turistas y vecinos. En relación con el primero de ellas, la sobrefrecuentación de determinados espacios públicos como consecuencia de la actividad turística se vincula por los redactores del planeamiento con una pérdida de la calidad del espacio urbano en aspectos como sus condiciones socioambientales o la movilidad ciudadana. Las razones de esta degradación de la calidad del espacio público se encontrarían en un aumento del ruido, la contaminación y los residuos generados por actividades vinculadas a la satisfacción de las demandas de la población flotante ${ }^{21}$. La CNMC (2018a: 8, 52) advierte de la incorrección de establecer un vínculo directo y exclusivo entre la actividad de alojamiento turístico en viviendas particulares y las citadas externalidades negativas, pues éstas no son exclusivas de las viviendas de uso turístico, ya que molestias como la congestión, los ruidos o el consumo de recursos medioambientales son generadas por cualquier turista, con independencia de la modalidad de alojamiento que elija, e, incluso, por cualquier ciudadano con independencia de su condición de visitante o de residente. Esta misma idea es recogida por la sentencia del Juzgado de lo Contencioso-administrativo núm. 6 de Valencia, de 27 de abril de 2016, que considera carente de justificación que el Ayuntamiento de esta ciudad exigiese la aplicación de la normativa sobre prevención de la contaminación y calidad ambiental -en forma de comunicación ambiental previa- a las viviendas de uso turístico, al no entender «[...] en qué medida la

19 Convendría, en todo caso, diferenciar entre las actividades comerciales relativas a productos y servicios que puedan ser disfrutados por los consumidores «a distancia», bien porque se trate de productos que puedan ser enviados materialmente al consumidor ( $v$. gr. ropa, calzado, alimentación, productos electrónicos, etc.), bien porque se trate de servicios a los que sea posible acceder de forma remota ( $v$. gr. programas informáticos, canales de televisión, entidades de intermediación turística, etc.); y aquéllas que solamente pueden ser consumidas in situ, como los alojamientos turísticos. La importancia de la ubicación geográfica de las primeras se ha relativizado con las nuevas tecnologías, mientras que en las segundas sigue siendo fundamental.

20 Tales medidas permiten, además, despejar las dudas de que la regulación limitadora de los usos del suelo responda a la presión de los agentes incumbentes, puesto que los organismos encargados de la promoción de la competencia advierten de que detrás de estas regulaciones se encuentra, a menudo, la protección de los operadores establecidos. Por tal razón, los poderes públicos deben mantener una posición neutral en la rivalidad entre los potenciales nuevos operadores y los preexistentes, puesto que esta lucha beneficia siempre al consumidor final.

21 Se califica así a las personas que no residen habitualmente en un lugar. Este concepto abarca tanto a turistas como a propietarios de segundas residencias, trabajadores desplazados temporalmente o viajeros en tránsito. 
REALA. Nueva Época - N.o 10, Octubre 2018 - ISSN: 1989-8975 - DOI: 10.24965/reala.v0i10.10566 - [Págs. 22-39]

Planificación urbanística del turismo: la regulación de las viviendas de uso turístico en Madrid y Barcelona

Alejandro Román Márquez

cesión de uso remunerada, y de forma habitual, de viviendas puede afectar al medio ambiente en mayor medida que un contrato civil de arrendamiento de vivienda sujeto a la $L A U »$ (Fundamento de derecho primero).

Los instrumentos de planificación urbanística de las viviendas turísticas de Madrid y Barcelona no explicitan las razones que llevan a sostener que los turistas hacen un uso más intenso del espacio público que el resto de ciudadanos, lo cuáles pueden concentrarse igualmente en determinados puntos de la ciudad por razones comerciales o de esparcimiento. En cualquier caso, estas externalidades son relativamente fáciles de minimizar mediante el reforzamiento de los servicios públicos de limpieza y transporte público y la reordenación de los espacios urbanos para facilitar el tránsito de personas ( $v$. gr. ampliación de aceras, peatonalización, interiorización de flujos de visitantes, etc.). Precisamente los impuestos pigouvianos sugeridos por los organismos encargados de la promoción de la competencia pueden sufragar parte del incremento de los gastos necesarios para implementar las medidas propuestas, contribuyendo además a incrementar los niveles de empleo público y privado.

En cuanto al segundo de los efectos adversos identificados por los responsables de la planificación urbanística, advierten éstos de que las diferentes dinámicas horarias de las poblaciones residente y visitante generan problemas que distorsionan la convivencia ciudadana y el descanso de los residentes, siendo especialmente graves en aquellas zonas en las que se ha producido un desequilibrio entre la población residente y la visitante, siendo estos últimos quienes «imponen» unas dinámicas que rompen el modelo de convivencia urbana. En mi opinión, los redactores de ambos planes adoptan una postura maximalista frente a esta potencial externalidad negativa, considerando que la presencia de estos «vecinos rotatorios» (González Jiménez, 2017: 114) genera indefectiblemente incomodidades para los moradores habituales. Sin embargo, la jurisprudencia ya se ha pronunciado en varias ocasiones al respecto, advirtiendo de que en ningún caso se puede entender que la actividad de alojamiento turístico en viviendas particulares sea de naturaleza inherentemente perjudicial o molesta ${ }^{22}$. Incluso, el propio legislador catalán ha considerado que las viviendas de uso turístico entran en la categoría de actividades inocuas, entendiéndose por tales aquéllas que, en atención a sus características, no producen molestias significativas ni afecciones considerables al medio ambiente, la seguridad de las personas o los bienes ${ }^{23}$.

La solución a los eventuales problemas de convivencia entre turistas y vecinos debe pasar, por lo tanto, por el recurso a los mecanismos previstos al efecto por la legislación sobre propiedad horizontal ${ }^{24}$. Así lo considera la CNMC (2018a: 53, 55), la cual propone, además, el establecimiento de sistemas de responsabilidad del arrendador en función de la diligencia demostrada a la hora de alquilar su vivienda a usuarios con una buena reputación previa ${ }^{25}$. A favor del uso prioritario de los mecanismos previstos en la legislación sobre propiedad horizontal se posicionan autores como Herrero Suárez (2017: 160), para quien las molestias generadas por los usuarios turísticos a los residentes habituales pueden ser combatidas más eficazmente «[...] por los propios interesados mediante las posibilidades que abre la legislación en materia de propiedad horizontal de hacer cesar la explotación turística, inicialmente, vía estatutos o, posteriormente, a través de acuerdos si se constata que esta constituye una actividad contraria a la normal convivencia vecinal». Debe tenerse muy presente, en cualquier caso, que estos mecanismos presentan, al menos, tres debilidades relevantes: a) en primer lugar, la lentitud característica de todo procedimiento judicial, pues las actuaciones contra vecinos molestos deben contar indefectiblemente con el consentimiento del Juez civil; b) las dificultades probatorias inherentes a unas conductas que, con carácter general, son producidas por huéspedes alojados durante estancias muy reducidas; y c) la imposibilidad de adoptar acuerdos relativos a la prohibición del uso turístico de las viviendas sin contar con el beneplácito unánime de la propiedad -puesto que, como es sabido, los usos de la propiedad inmobiliaria horizontal deben quedar recogidos en los estatutos de la

22 Entre otras, la sentencia del Tribunal Superior de Justicia de Cataluña de 12 de junio de 2017 (recurso núm. 55/2017) señala que «[...] la actividad de uso turístico de los pisos situados en edificios regidos por las normas de la propiedad horizontal no son actividades ilegales ni ilícitas per se y en abstracto consideradas si no se hallan prohibidas por los Estatutos y se encuentran autorizadas administrativamente pero puede acordarse el cese de la actividad si por su modo de ejercicio producen en la Comunidad alteraciones graves en la normal convivencia» (Fundamento jurídico cuarto). En el mismo sentido, la Autoridad Vasca de la Competencia (AVC, 2017: 18) considera innecesario y desproporcionado limitar o prohibir el uso turístico de las viviendas en todas las comunidades de propietarios, incluso en aquéllas en la que los vecinos sean abiertamente proclives a su desarrollo.

23 Art. 12.2 letra a) de la Ley 16/2015, de 21 de julio, de simplificación de la actividad administrativa de la Administración de la Generalidad y de los Gobiernos locales de Cataluña, en relación con su Anexo I (I.55.552).

24 Como la acción de cesación de actividades molestas, la privación del derecho al uso de la vivienda durante un máximo de tres años, el lanzamiento inmediato de los ocupantes no propietarios y la indemnización de los daños causados (art. $7 .{ }^{\circ} .2$ de la Ley 49/1960, de 21 de julio, sobre propiedad horizontal).

25 Sobre este mecanismo vid. ACCO (2016b). 
REALA. Nueva Época - N. 10, Octubre 2018 - ISSN: 1989-8975 - DOI: 10.24965/reala.v0i10.10566 - [Págs. 22-39]

Planificación urbanística del turismo: la regulación de las viviendas de uso turístico en Madrid y Barcelona

Alejandro Román Márquez

comunidad de propietarios y para su modificación se requiere unanimidad-. En relación con esta última posibilidad, sería conveniente reflexionar acerca de la oportunidad de un cambio legislativo que permitiese la prohibición estatutaria de estas actividades mediante mayorías cualificadas, compensando adecuadamente a los propietarios que ya viniesen ejerciendo esta actividad.

Para la CNMC (2018a: 47), las restricciones a las viviendas de uso turístico no responden en este caso a un verdadero fallo del mercado atribuible a la existencia de externalidades negativas y, por lo tanto, no respetan el principio de necesidad exigible a este tipo de medidas extremas. Y ello porque, en su opinión, estas medidas se fundamentan en la cuestionable hipótesis de que las viviendas de uso turístico generan más problemas de convivencia que otros usos residenciales, como las viviendas compartidas, los arrendamientos a estudiantes, aquéllos en los que habitan mascotas, etc., y que no han sido objeto de disposiciones especiales ${ }^{26}$. En cualquier caso, y más allá de los eventuales conflictos que puedan existir entre turistas y residentes, así como de la oportunidad de las medidas elegidas para solucionarlos, lo que sí resulta evidente es que la actividad turística implica un uso intensivo de determinados elementos comunes de los inmuebles -pasillos, ascensores, portales, etc.- respecto del que hacen los residentes habituales, contribuyendo en mayor medida a su deterioro ${ }^{27}$. Por tal razón, debería considerarse la posibilidad de elevar obligatoriamente la participación de los propietarios de viviendas de uso turístico en los gastos comunes de la comunidad horizontal, compensado de este modo el mayor deterioro del inmueble, del que son directamente responsables ${ }^{28}$.

El tercero de los objetivos utilizados como justificación de las restricciones impuestas a las viviendas de uso turístico es la promoción del derecho fundamental a una vivienda digna. Para los autores de los planes analizados el crecimiento de la actividad turística estaría provocando una presión sobre este derecho que se manifiesta en un aumento generalizado de los precios de la vivienda. El objetivo de las medidas adoptadas tendría como finalidad el reequilibrio del mercado y la garantía del derecho de los ciudadanos a disfrutar de condiciones de vida urbana y de vivienda que favorezcan la cohesión social, buscando el desarrollo sostenible, económico, ambiental y social de la población. Se parte de la idea de que la regulación de los usos del suelo que fomente la mezcla equilibrada de grupos sociales, usos y actividades es un mandato inherente al derecho fundamental a la vivienda. Parece evidente que los redactores del planeamiento urbanístico de las viviendas de uso turístico no se ciñen al derecho a una vivienda digna constitucionalmente garantizado, sino a un derecho más amplio e innovador, pero también de contornos mucho más imprecisos ${ }^{29}$, como es el «derecho a la ciudad» ${ }^{30}$.

La Carta Mundial por el Derecho a la Ciudad define este derecho como «[...] el usufructo equitativo de las ciudades dentro de los principios de sustentabilidad, democracia, equidad y justicia social. Es un derecho colectivo de los habitantes de las ciudades, en especial de los grupos vulnerables y desfavorecidos, que les confiere legitimidad de acción y de organización, basado en sus usos y costumbres, con el objetivo de alcanzar el pleno ejercicio del derecho a la libre autodeterminación y un nivel de vida adecuado [...]». La propia Carta vincula este derecho con el derecho a la vivienda (art. I.2), pero de una forma diferente a como lo hacen los redactores del PEUAT. Este documento compele a las ciudades a adoptar medidas que garanticen a todos los ciudadanos que los gastos de vivienda sean soportables de acuerdo con sus ingresos, que las viviendas reúnan condiciones de habitabilidad, que estén ubicadas en un lugar adecuado y se adapten a las características culturales y étnicas de quienes las habitan. Igualmente deben facilitar una oferta adecuada de viviendas y equipamientos urbanos, establecer programas de subsidio y financiación de políticas de vivienda,

26 En el mismo sentido, la Sentencia del Tribunal Superior de Justicia de Cataluña núm. 37/2016, de 19 de mayo, recuerda que el uso intensivo de los elementos comunes por el trasiego de ocupantes no es exclusivo de este tipo de actividad, sino de otras como despachos profesionales o locales abiertos al público (Fundamento de derecho tercero).

27 Este uso intensivo ha sido puesto de relieve por la jurisprudencia. Vid., entre otras, la sentencia de la Audiencia Provincial de La Coruña núm. 164/1996, de 16 de mayo.

${ }_{28}$ Esta posibilidad ya habría sido apuntada por la Sentencia del Tribunal Superior de Justicia de Cataluña núm. 37/2016, de 19 de mayo, que señala que los daños derivados del uso intensivo de los elementos comunes del inmueble derivados del trasiego de turistas "[...] puede ser compensado mediante la activación del mecanismo previsto en el art. 553-45.4 CCCat, conforme al cual el título de constitución o la Junta pueden establecer un incremento de la participación en los gastos comunes que corresponde a un elemento privativo concreto, en el caso del uso o disfrute especialmente intensivo de elementos o servicios comunes como consecuencia del ejercicio de actividades empresariales o profesionales en el piso o local» (Fundamento de derecho tercero).

29 Como advierte UCEDA NAVAS (2016: 50), el derecho a la ciudad es un concepto «[...] tan amplio, tan poco delimitado, que en él se pueden introducir todos los aspectos que se deseen, por lo que el cariz que tome o las definiciones que se le den, pueden llegar a ser incluso antagónicas». Mientras que algunos autores incluyen el derecho a la vivienda como parte integrante del derecho a la ciudad (GARNIER, 2011), otros identifican a este último con la participación ciudadana directa en la gestión de las ciudades (BANDRÉS SÁNCHEZ-CRUZAT, 2014: 98).

30 La Memoria del PEUAT hace referencia a este derecho en la introducción a su marco de referencia (pág. 9). La paternidad de este concepto recae sobre LEFEBVRE (1968). Más recientemente PAREJO ALFONSO (2015). 
REALA. Nueva Época - N. 10, Octubre 2018 - ISSN: 1989-8975 - DOI: 10.24965/reala.v0i10.10566 - [Págs. 22-39]

Planificación urbanística del turismo: la regulación de las viviendas de uso turístico en Madrid y Barcelona

Alejandro Román Márquez

regularizar la tenencia del suelo y garantizar la seguridad jurídica de la propiedad inmobiliaria, priorizar a los grupos vulnerables y respetar la igualdad de género en los documentos de posesión y propiedad inmobiliaria.

Con independencia del contenido concreto que pretenda atribuirse al derecho fundamental a una vivienda digna, no parece que pueda en ningún caso comprender el derecho a residir en un lugar determinado de la ciudad -en este caso, en las áreas centrales de las ciudades de Madrid y Barcelona, las más afectadas por el incremento del precio de la vivienda atribuido a la actividad turística-. Pero, incluso en el caso de que el derecho a una vivienda digna pudiese abarcar el derecho a elegir nuestro lugar de residencia, debería ponderarse con el derecho del propietario de la vivienda a obtener el máximo rendimiento económico de su propiedad dentro de los límites impuestos por su función social -la cual, insisto, no entiendo que pueda justificar un recorte de tal envergadura al derecho fundamental a la propiedad privada y a la libertad de empresa basado en razones como las expuestas-. Por otra parte, desde la perspectiva de la sostenibilidad económica se considera a las viviendas de uso turístico como un ejemplo de utilización innovadora y eficiente de activos, puesto que contribuyen a eliminar la denominada "capacidad de improductividad»-idling capacity-, es decir, la falta de aprovechamiento o infrautilización de los bienes, en este caso, de las viviendas particulares (Miralles Marugán y Villar Lama, 2016: 24). Como advierte Doménech Pascual (2018: 51) «[e]/ mero hecho de que el precio de los usos alternativos - v. gr. el residencial- de las viviendas se incremente como consecuencia de la mayor rentabilidad del uso turístico no constituye una externalidad negativa ni un fallo del mercado que justifique la intervención pública encaminada a reducir ese precio. Limitar el uso más beneficioso de un bien simplemente para reducir el precio del segundo uso más beneficioso carece de sentido desde el punto de vista de la racionalidad económica: es ineficiente; implica una destrucción de bienestar social. Tiene tan poco sentido como prohibir las oficinas en el centro de una ciudad a fin de contener el precio de las viviendas allí situadas».

Los organismos encargados de la defensa de la competencia directamente niegan la mayor con relación a las causas que legitiman este objetivo (CNMC, 2018a: 9, 53; ACCO, 2017: 11, 12), al considerar que no existen evidencias empíricas suficientes como para atribuir a la proliferación de viviendas de uso turístico el alza en los precios de la vivienda experimentados en los últimos años en ambas ciudades o, al menos, no de forma exclusiva o preponderante (VVVA, 2018a; Duatis et al., 2016). La recuperación económica, el aumento de la demanda cualificada o la disminución de la oferta de viviendas en alquiler como consecuencia de la reactivación del mercado de compraventa son identificados como factores responsables del aumento de los precios del alquiler residencial. Ninguno de los dos organismos niega que la existencia de viviendas de uso turístico y la eventual rentabilidad que genera para su propietario incida en la conformación de los precios del alquiler, pero consideran que no es suficientemente clara la relación directa y exclusiva que parecen atribuirle los redactores de ambos planes. Además, debe tenerse presente que el aumento de los precios de la vivienda debe ponerse en relación con la principal alternativa a las viviendas de uso turístico, puesto que si no hubiese aumentado la oferta de éstas se habría producido un mayor crecimiento de la construcción de hoteles y apartahoteles para atender a la demanda de alojamiento de turistas, lo cual supondría igualmente detraer viviendas residenciales para dedicarlas íntegramente al alquiler turístico, con efectos equivalentes sobre el precio de la vivienda. La propuesta de estos organismos pasa por una regulación más flexible y responsiva de este fenómeno, considerando más adecuados mecanismos como tributos -tasas- cuya recaudación sea destinada a financiar medidas orientadas a incidir en el nivel de precios del alquiler de vivienda residencial como, v. gr., la rebaja del Impuesto sobre Bienes Inmuebles de aquéllos propietarios de viviendas que no excedan un determinado nivel de precios, así como otras medidas de carácter social o que incidan en el mercado de la vivienda social.

\section{RESTRICCIONES A LA EXPLOTACIÓN DE VIVIENDAS DE USO TURÍSTICO EN LAS CIUDADES DE BARCELONA Y MADRID}

\subsection{Restricciones contenidas en el Plan Especial Urbanístico para la regulación} de los establecimientos de alojamiento turístico, albergues de juventud, residencias colectivas docentes de alojamiento temporal y viviendas de uso turístico de la Ciudad de Barcelona

EI PEUAT condiciona el establecimiento de viviendas de alojamiento turístico a los siguientes requisitos:

a) Cumplimiento de los requisitos establecidos en el Decreto 159/2012, de 20 de noviembre, de establecimientos de alojamientos de uso turístico y de viviendas de uso turístico, y demás normativa sectorial turística autonómica. 
REALA. Nueva Época - N. 10, Octubre 2018 - ISSN: 1989-8975 - DOI: 10.24965/reala.v0i10.10566 - [Págs. 22-39]

Planificación urbanística del turismo: la regulación de las viviendas de uso turístico en Madrid y Barcelona

Alejandro Román Márquez

b) Cumplimiento de la normativa municipal aplicable y, especialmente, de la Ordenanza municipal que, en su caso, regule este tipo de alojamiento.

c) Ubicación en un inmueble que no estuviese destinado a vivienda con anterioridad al 1 de julio de $2015^{31}$

d) Ubicación distinta a la planta baja (lo cual incluye a las viviendas unifamiliares ${ }^{32}$ ).

e) Admisión del uso turístico del inmueble por el planeamiento urbanístico.

f) Adecuación a las condiciones zonales previstas en el PEUAT.

Como se señaló al inicio de este trabajo, la posibilidad de establecimiento de nuevas viviendas de uso turístico en la ciudad de Barcelona depende de su concreta ubicación, pues el PEUAT delimita diferentes áreas territoriales dentro de ésta, cada una de ellas con unas posibilidades y condicionantes diferentes. Estas «Zonas Específicas (ZE)» son cuatro:

a) La Zona Específica 1 (ZE-1) se configura como un área de «decrecimiento natural» ${ }^{33}$. En esta zona ${ }^{34}$, la disminución del número total de viviendas de uso turístico censadas posibilita la autorización de nuevas viviendas de uso turístico en la Zona Específica 3.

b) La Zona Específica 2 (ZE-2) es una «Zona de mantenimiento» ${ }^{35}$, y en ella la disminución del número total de viviendas de uso turístico censadas posibilita la autorización de nuevas viviendas de uso turístico en las Zonas Específicas 2 o 3.

c) La Zona Específica 3 (ZE-3) es una zona de «crecimiento contenido» ${ }^{36}$, y en ella podrán autorizarse nuevas viviendas de uso turístico en alguno de los dos siguientes supuestos: a) cuando disminuya el número total de viviendas de uso turístico censadas en esta zona; b) cuando disminuya el número total de viviendas de uso turístico censadas en las Zonas Específicas 1 y 2, con el límite máximo de 387 establecimientos de viviendas de uso turístico. Para la autorización de nuevas viviendas de uso turístico en las Zonas Especiales 1 y 2 será necesario, además, que la manzana en la que se ubiquen no supere la densidad máxima de $1,48 \%$, contando las viviendas de uso turístico y viviendas habituales existentes en la manzana, o hasta colmatar un edificio completo, a excepción de su planta baja -en las que, como se ha indicado, no se admite la ubicación de viviendas de uso turístico-, con un máximo de diez viviendas de uso turístico y, en su caso, con usos de no vivienda.

d) Finalmente, la Zona Específica 4 (ZE-4) está dividida a su vez en cuatro subzonas y corresponden a áreas territoriales que han sido objeto de planeamientos urbanísticos específicos y que se encuentran en proceso de desarrollo ${ }^{37}$. En esta zona está prohibido el establecimiento de viviendas de uso turístico.

El Distrito de Ciutat Vella constituye un supuesto de regulación específica y diferenciada con respecto al resto del ámbito de aplicación territorial del PEUAT en atención a las particularidades y, especialmente, a los precedentes regulatorios existentes. En este distrito, ubicado en la Zona Específica 1, las viviendas de uso turístico censadas pueden agruparse en edificios en los que no exista ninguna entidad dedicada a vivienda principal o secundaria. Esta agrupación no es, en ningún caso, obligatoria, sino completamente voluntaria, y ello porque una obligación en este sentido, contenida en el Plan Especial de Establecimientos de Concurrencia Pública, Hostelería y Otras Actividades en Ciutat Vella aprobada en $2013^{38}$ ya fue anulada por la sentencia del Tribunal Superior de Justicia de Cataluña núm. 323/2017, de 29 de mayo ${ }^{39}$.

${ }^{31}$ En esta fecha la Comisión de Gobierno del Ayuntamiento de Barcelona acordó suspender el otorgamiento de autorizaciones para la apertura, instalación o ampliación de todas las modalidades de alojamientos turísticos. Para DOMÉNECH PASCUAL (2018: 72) se trata de una medida injustificable, puesto que prohibir que quienes en esa fecha estaban destinando el inmueble a uso como vivienda $-v$. $g r$. como domicilio habitual- la dediquen ahora a uso turístico «premia» a los propietarios que estaban infrautilizando su vivienda y "castiga» a los que sí la estaban aprovechando, lo que califica de «ciertamente absurdo» y «contrario al espíritu que supuestamente anima» el PEUAT.

32 Manual Operativo del PEUAT, pág. 9.

${ }_{33}$ Incluye los distritos de Ciutat Vella, los barrios de l'Antiga Esquerra y Dreta del Ensanche, parte del barrio de Sant Antoni, los barrios de Poble Sec, Hostafrancs, Villa de Gràcia, la Villa Olímpica del Poblenou y el barrio del Poblenou.

${ }^{34}$ Salvo el Distrito de Ciutat Vella.

35 Incluye los barrios de la Nova Esquerra del Ensanche, parte de Sant Antoni, la Sagrada Familia, Fort Pienc, la Font de la GuatIla, Sants, Les Corts, Sant Gervasi-Galvany, parte de los barrios de Putxet, Farró, Vallcarca y Els Penitents, La Salut, Camp d'en Grassot y Gràcia Nova, Baix Guinardó, y los barrios del Parque y la Laguna del Poblenou, Diagonal Mar y el Frente Marítimo del Poblenou.

36 Incluye el resto de suelo urbano no incluido en las zonas ZE-1, ZE-2 y ZE4.

37 Marina del Prat Vermell, La Sagrera y Nord.

${ }^{38}$ Aprobada en sesión plenaria de 24 de julio de 2013, Boletín Oficial de la Provincia de Barcelona de 16 de septiembre de 2013.

39 La modificación del Plan Especial de Establecimientos de Concurrencia Pública, Hostelería y Otras Actividades en Ciutat Vella aprobada en 2013 concedió un plazo de seis años para que las viviendas de uso turístico se agrupasen en edificios enteros o edificios 
REALA. Nueva Época - N. 10, Octubre 2018 - ISSN: 1989-8975 - DOI: 10.24965/reala.v0i10.10566 - [Págs. 22-39]

Planificación urbanística del turismo: la regulación de las viviendas de uso turístico en Madrid y Barcelona

Alejandro Román Márquez

El procedimiento administrativo para la autorización de viviendas de uso turístico incluye un informe previo elaborado por la Oficina del Censo en el que ésta comprueba el cumplimiento de todos los requisitos fijados en el PEUAT. Este informe posee naturaleza preceptiva y vinculante, pues solamente cuando sea evacuado en sentido favorable podrá comunicarse al órgano municipal competente el inicio de la actividad. Se trata de una auténtica autorización encubierta ${ }^{40}$, en el sentido de constituir un control ex ante de la legalidad de la actividad económica que se pretende iniciar. Tal y como dispone el artículo 4.6 de la Directiva de Servicios, se considera sometido a un régimen de autorización «[...] cualquier procedimiento en virtud del cual el prestador o el destinatario estén obligados a hacer un trámite ante la autoridad competente para obtener un documento oficial o una decisión implícita sobre el acceso a una actividad de servicios o su ejercicio». Los redactores del PEUAT no explicitan qué razones imperiosas de interés general ${ }^{41}$ legitiman la imposición de un régimen autorizatorio en esta materia, y tampoco acreditan el cumplimiento de los principios de no discriminación y proporcionalidad, por lo que su adecuación a Derecho es más que cuestionable.

EI PEUAT exige igualmente autorización cuando se pretenda destinar la totalidad de un edificio a viviendas de uso turístico u otras actividades compatibles. En tales supuestos, el cien por cien de la propiedad debe obtener una licencia urbanística de modificación de uso o actividad ${ }^{42}$. La obtención de esta licencia debe ser previa a la solicitud del referido informe de la Oficina del Censo y, por tanto, a la comunicación de inicio de la actividad. Esta autorización excluye la utilización de cualquier entidad del edificio como vivienda principal o secundaria, debiendo inscribirse en el Registro de la Propiedad tal prohibición.

\subsection{Restricciones contenidas en el Plan Especial de Regulación del Uso de Servicios Terciarios en la clase de Hospedaje de Madrid}

EI PERUH incluye en su ámbito de aplicación a todas aquellas viviendas particulares que sean ofertadas por sus propietarios como alojamientos turísticos por un plazo superior a tres meses al año, dejando al margen a las viviendas arrendadas por periodos inferiores. La razón está en el Decreto 79/2014, de 10 de julio, por el que se regulan los apartamentos turísticos y las viviendas de uso turístico de la Comunidad de Madrid, que exige profesionalidad y habitualidad a la actividad de alojamiento turístico en viviendas particulares, y determina esta circunstancia en función de un elemento temporal: «[s]e entenderá por habitualidad el ejercicio de la actividad turística durante un período mínimo de tres meses continuados durante el año natural» (art. 3.2). La CNMC (2018a: 44 y 45) desaprueba el uso de elementos cuantitativos y/o temporales para establecer la distinción entre proveedores particulares y profesionales de alojamiento turístico. La CNMC entiende que la distinción entre particulares y profesionales en función del número de días que los propietarios exploten sus viviendas restringe la oferta de viviendas de uso turístico, ya que una cantidad considerable de propietarios preferirán retirar sus viviendas del mercado una vez alcanzada la duración máxima para seguir siendo considerados proveedores particulares y de este modo evitar incurrir en los costes adicionales que supone prestar el servicio de alojamiento como profesional ( $v$. gr. disponer de un acceso independiente, conexión a internet, licencia de uso, etc.). Este organismo se muestra partidario de no realizar distinciones sobre la profesionalidad o no de los proveedores de viviendas de uso turístico, evitando además la determinación de umbrales cuantitativos difícilmente justificables - por arbitrarios- y los denominados errores de salto, en virtud de los cuáles el tratamiento que da a la norma a los proveedores de viviendas de uso turístico es completamente distinto por variar solamente una jornada respecto del total de las ofertadas al mercado (en

con otros usos que no fuese el de vivienda. Expirado este plazo, se extinguirían las licencias de viviendas de uso turístico que no se hubiesen agrupado. El Tribunal Superior de Justicia de Cataluña anula esta previsión «[...] por prescribir la extinción de las licencias sin seguir ningún procedimiento previo de extinción, ni determinación de la compensación o indemnización procedente por esa extinción. [...] Como se ha dicho en el fundamento anterior, procede declarar la nulidad [...] por decretar la extinción de los títulos habilitantes por el mero transcurso del plazo previsto [...] al margen de un procedimiento de reparcelación o expropiación, o de un procedimiento de revocación de licencia con la compensación o indemnización correspondiente [...]» (Fundamentos de Derecho quinto y sexto).

40 En relación con éstas, véase ROMÁN MÁRQUEZ (2018: 545).

41 Artículo 9 de la Directiva de Servicios, concretados por la Ley 17/2009, de 23 de noviembre, sobre el libre acceso a las actividades de servicios y su ejercicio (art. 5) en el orden público, la seguridad pública, la salud pública y la protección del medio ambiente.

42 En el supuesto de que se trate de un edificio de viviendas. Cuando el edificio no estuviese dedicado a vivienda será necesaria licencia de obra mayor de cambio de uso. En este segundo caso también debe inscribirse en el Registro de la Propiedad, además de la prohibición expresa de que cualquier entidad del edificio se dedique a vivienda principal o secundaria, el uso específico del edificio, esto es, el uso de vivienda turística u otras actividades compatibles (Manual Operativo del PEUAT, pág. 18). 
REALA. Nueva Época - N. 10, Octubre 2018 - ISSN: 1989-8975 - DOI: 10.24965/reala.v0i10.10566 - [Págs. 22-39]

Planificación urbanística del turismo: la regulación de las viviendas de uso turístico en Madrid y Barcelona

Alejandro Román Márquez

el caso de Madrid, el error de salto se localiza entre las noches número noventa y noventa y uno ${ }^{43}$. Como recuerda Beirak (2018), los usos se definen por su naturaleza, y no por su duración. También en este caso.

EI PERUH exige la posesión de una licencia de uso de hospedaje para explotar turísticamente una vivienda. Solo se prescinde de esta exigencia respecto de los edificios localizados en el tercer anillo ${ }^{44}$ en los que ya se admiten otras clases de uso terciario del suelo, como oficinas o comercios. En estos edificios se admite el cambio de uso residencial a turístico sin necesidad de autorización turística previa. Como en el caso barcelonés, tampoco se justifica debidamente la existencia de razones jurídicamente aceptables para la exigencia de un régimen autorizatorio, sin que puedan conocerse las razones por las que respecto de esta actividad económica se considera insuficiente la declaración responsable.

El resto de las limitaciones varían igualmente en función de la localización de la vivienda. Respecto de las viviendas emplazadas en los anillos primero y segundo ${ }^{45}$, se exige que éstas cuenten con un acceso independiente, no pudiendo utilizar puertas de entrada, portales o ascensores comunes al resto de viviendas. Además, este acceso no puede ser directo desde la calle a los alojamientos, sino que deben contar con una recepción o similar situada previamente a aquéllos. Esta última condición estaría orientada, principalmente, a los alojamientos situados a pie de calle, por lo que resultan admisibles que las viviendas de uso turístico se ubiquen en planta baja, a diferencia de lo que ocurre en Barcelona. En el tercer anillo las viviendas estarán sometidas a idéntico requisitos cuando estén ubicadas en edificios de uso exclusivamente residencial, pero no así cuando se admitiesen ya otros usos terciarios.

La exigencia de que las viviendas de uso turístico cuenten con acceso y ascensores independientes para el uso exclusivo de sus clientes, a semejanza de lo que sucede con otros establecimientos de alojamiento turístico, como los hoteles ${ }^{46}$, debe calificarse como innecesaria y desproporcionada para alojamientos de esta naturaleza, caracterizados precisamente por ser viviendas ordinarias ubicadas en edificios residenciales, a diferencia de los hoteles, conformados por un conjunto homogéneo de unidades de alojamiento y de servicios orientados específicamente a la actividad turística. Si la finalidad de esta drástica segregación entre colectivos es evitar las incomodidades que puedan afectar a los residentes habituales del inmueble o evitar el menoscabo de elementos comunes del edificio, existen otros mecanismos más respetuosos con el principio de proporcionalidad, de los que ya se ha dado cuenta supra. Resulta obvio que este requisito esconde una prohibición generalizada de las viviendas de uso turístico, pues prácticamente ninguna está en condiciones de cumplir con esta exigencia ${ }^{47}$, y además no se exige un requisito similar a otros establecimientos de alojamiento turístico, como las pensiones ${ }^{48}$, lo que podría suponer una vulneración del principio de no discriminación.

\section{REFLEXIÓN FINAL: OBJETIVOS BIENINTENCIONADOS, DIAGNÓSTICO DEFICIENTE Y CONSECUENCIAS IMPREVISIBLES}

Resulta innegable reconocer que la planificación urbanística madrileña y barcelonesa está inspirada por un conjunto de objetivos loables, como son la protección de bienes jurídicos tan importantes como la calidad de vida de los ciudadanos y el acceso a una vivienda digna. Sin embargo, una intervención tan intensa en el mercado puede generar mayores problemas que los que se pretenden corregir. Debe tenerse muy presente que las restricciones artificiales del mercado generan prácticas especulativas por parte de los operadores incumbentes. Ante un bloqueo absoluto del mercado, como el que se produce con ocasión de las moratorias turísticas, el precio de venta de los permisos de explotación de los alojamientos turísticos en el mercado secundario se incrementa -al igual que ha sucedido tradicionalmente en el sector de los taxis o de las farmacias $^{-49}$, y en el caso de viviendas de uso turístico, también lo harán las viviendas que posean uno de

\footnotetext{
43 En el mismo sentido ACCO (2016a: 12).

${ }_{44}$ El tercer anillo comprende diferentes barrios de los Distritos Tetuán, Chamartín, Salamanca, Retiro, Arganzuela, Usera, Carabanchel, Latina y Moncloa-Aravaca.

${ }^{45}$ El primer anillo coincide con el Distrito Centro, mientras que el segundo comprende el distrito de Chamberí completo y parte de los Distritos Chamartín, Salamanca, Retiro, Arganzuela y Moncloa-Aravaca.

${ }^{46}$ Artículo 26.1 de la Ley 1/1999, de 12 de marzo, de Ordenación del Turismo de la Comunidad de Madrid.

47 El porcentaje de viviendas excluidas ascendería, según algunas estimaciones, al 95\% (LANTIGUA, 2018).

48 Artículo 35.2 del Decreto 159/2003, de 10 de julio, de Ordenación de Establecimientos Hoteleros de la Comunidad de Madrid.

49 Valga como ejemplo esta noticia: https://www.lavanguardia.com/local/barcelona/20170726/43109208799/moratoria-hotelerabarcelona-provoca-inflacion-inversion.html
} 
REALA. Nueva Época - N.10, Octubre 2018 - ISSN: 1989-8975 - DOI: 10.24965/reala.v0i10.10566 - [Págs. 22-39]

Planificación urbanística del turismo: la regulación de las viviendas de uso turístico en Madrid y Barcelona

Alejandro Román Márquez

estos permisos. El aumento del precio de estas últimas puede inducir igualmente un aumento generalizado del precio de la vivienda, pues al salir éstas del mercado residencial, disminuyen el número de viviendas disponibles para compraventa y alquiler, con el señalado efecto de elevar los precios del resto de las viviendas disponibles. En las sociedades desarrolladas el mercado provee la práctica totalidad de los bienes y servicios demandados por los consumidores, por lo que la escasez, que es la condición indispensable para que exista especulación, solamente puede ser generada por los poderes públicos mediante restricciones de naturaleza normativa o administrativa ( $v$. gr. la planificación urbanística, la limitación de permisos vinculados con la restauración y el ocio en zonas saturadas, las licencias de vehículos de turismo con conductor, etc.). En el pasado se pusieron en práctica otras muchas iniciativas restrictivas del mercado con objetivos igualmente encomiables, pero con resultados perversos tanto para propietarios como para consumidores, como sucedió con el control de precios del alquiler de la vivienda durante la dictadura.

Reemplazar las leyes del mercado para fijar desde las Administraciones públicas la cantidad y localización de las actividades económicas se ha demostrado históricamente no solo ineficaz, sino extremadamente perjudicial para los colectivos que se pretenden beneficiar. Además de los efectos negativos expuestos a lo largo de este trabajo sobre la cantidad y calidad de la oferta turística y, por extensión, sobre los propios consumidores, debe tenerse igualmente presente que la zonificación restrictiva de los usos del suelo aprobada en ambas ciudades puede tener también el efecto de desplazar las viviendas turísticas desde las zonas centrales de las ciudades -en las que las restricciones son más intensas- a la periferia, lo que provocaría un incremento de los precios en estas zonas, con la consiguiente expulsión de los demandantes de vivienda con menos recursos económicos, que cada vez deberán buscarla en áreas más apartadas de los centros urbanos, con los inconvenientes que ello puede tener en materia de movilidad y de cohesión social. Como propone el PERUH, «[..] extender la actividad de alojamiento turístico a otras zonas de la ciudad, redistribuyendo la actividad económica y descargando la concentración del centro histórico [...]» no es una medida inocua, sino que tendrá consecuencias socioeconómicas sobre las zonas en las que se ubiquen las nuevas viviendas de uso turístico.

Desde el plano estrictamente jurídico, los redactores de los planes parecen no tener suficientemente presente que el ordenamiento jurídico comunitario y español establece limitaciones a la intervención restrictiva de los poderes públicos sobre las actividades económicas. Las medidas restrictivas solamente son compatibles con el ordenamiento jurídico cuando se fundamentan en razones reconocidas como de interés general y además éstas resultan explicitadas de forma motivada. Así ocurre con el sometimiento de la actividad de alojamiento en viviendas de uso turístico al régimen de autorización, que en virtud de la Directiva de Servicios únicamente es admitido cuando no resulte discriminatorio, su necesidad esté justificada por una razón imperiosa de interés general y el objetivo pretendido no pueda lograrse mediante una medida menos restrictiva (esto es, cuando el control a posteriori se produjese demasiado tarde para ser realmente eficaz). Además, se prohíbe a los Estados miembros condicionar el acceso a una actividad de servicios o su ejercicio a una prueba económica, en el sentido de supeditar la concesión del permiso a que se demuestre la existencia de una necesidad económica o de una demanda en el mercado, a que se evalúen los efectos económicos de esta actividad o a que se aprecie si ésta se ajusta a los objetivos de programación económica fijados por la autoridad competente (art. 14.5). Nos encontramos, pues, ante una serie de limitaciones respecto de determinadas actividades económicas cuya legalidad debe ser escrupulosamente examinada a la luz de la legislación europea sobre libre prestación de servicios.

Finalmente, resulta imprescindible realizar una ponderación de los diferentes intereses y derechos en juego -medio ambiente, cohesión social, propiedad, libre empresa, vivienda digna, etc.- para determinar cuáles son los superiores, de forma que al proteger unos no se vulneren otros que pueden ser prioritarios, 0 directamente se atribuya el carácter de derecho fundamental a pretensiones que no merecen ser calificadas como tales. Como se ha señalado en estas páginas, resulta necesario reflexionar sobre si el derecho fundamental a una vivienda digna comprende el derecho de los ciudadanos a residir en un lugar concreto de la ciudad y, en caso de que así fuese, si este derecho sería superior al derecho de los propietarios de las viviendas a obtener el mayor rendimiento económico de éstas $-\mathrm{y}$, consecuentemente, a no sostener en solitario iniciativas de naturaleza social cuya responsabilidad corresponde principalmente a los poderes públicos-.

\section{REFERENCIAS BIBLIOGRÁFICAS}

AUTORIDAD CATALANA DE COMPETENCIA (ACCO) (2014): Recomendaciones sobre la regulación detallada de los usos del suelo desde la óptica de la competencia, Ref. núm. ES 8/2014, diciembre. 
REALA. Nueva Época - N. 10, Octubre 2018 - ISSN: 1989-8975 - DOI: 10.24965/reala.v0i10.10566 - [Págs. 22-39]

Planificación urbanística del turismo: la regulación de las viviendas de uso turístico en Madrid y Barcelona

Alejandro Román Márquez

AUTORIDAD CATALANA DE COMPETENCIA (ACCO) (2015): Informe IR 22/2015, de 9 de septiembre.

AUTORIDAD CATALANA DE COMPETENCIA (ACCO) (2016a): Informe IR 24/2016 sobre el Proyecto de reglamento de turismo de Cataluña (versión de agosto de 2016), septiembre.

AUTORIDAD CATALANA DE COMPETENCIA (ACCO) (2016b): Transacciones entre iguales (P2P). Un paso adelante, Ref. núm. 10/2015, mayo.

AUTORIDAD CATALANA DE COMPETENCIA (ACCO) (2017): Nota sobre la aprobación definitiva del Plan especial urbanístico de alojamientos turísticos (PEUAT) de Barcelona, Ref. núm. OB 33/2017.

AUTORIDAD VASCA DE COMPETENCIA (AVC) (2017): Informe sobre la modificación pormenorizada del Plan General de Ordenación Urbana de Bilbao en lo relativo a la regulación del uso del alojamiento turístico, Proyecto LEA/AVC núm. 251-PROM-2017.

AUTORIDAD VASCA DE COMPETENCIA (AVC): Informe al Anteproyecto de la Ley de Turismo de Euskadi.

BANDRÉS SÁNCHEZ-CRUZAT, J. M. (2014): "El derecho a la ciudad", en Cuadernos de Derecho Local, núm. 35, junio, págs. 97-103.

BEIRAK, N. (2018): "Madrid será Magaluf: así extiende el Ayuntamiento la plaga del alquiler turístico", en El Confidencial, 23 de agosto. Disponible en: https://blogs.elconfidencial.com/cultura/tribuna/2018-08-23/ arquitectura-turisficacion-madrid-airbnb_1606857/.

COMISIÓN NACIONAL DE LOS MERCAD̄OS Y DE LA COMPETENCIA (CNMC) (2015): Informe económico sobre el Decreto 113/2015, de 22 de mayo, por el que se aprueba el reglamento de las viviendas vacacionales de la comunidad autónoma de Canarias, LA/03/15.

COMISIÓN NACIONAL DE LOS MERCADOS Y DE LA COMPETENCIA (CNMC) (2016): Estudio sobre los nuevos modelos de prestación de servicios y economía colaborativa -resultados preliminares-, E/CNMC/004/15, marzo.

COMISIÓN NACIONAL DE LOS MERCADOS Y DE LA COMPETENCIA (CNMC) (2018a): Estudio sobre la regulación de las viviendas de uso turístico en España, E/CNMC/3/18.

COMISIÓN NACIONAL DE LOS MERCADOS Y DE LA COMPETENCIA (CNMC) (2018b): La CNMC recurre la normativa urbanística municipal de viviendas turísticas de Madrid, Bilbao y San Sebastián, nota de prensa, 7 de agosto de 2018. Disponible en: https://www.cnmc.es/novedades/2018-08-07-la-cnmc-recurre-la-normativaurbanistica-municipal-de-viviendas-turisticas-de.

CONSEJO DE LA COMPETENCIA DE ANDALUCÍA (CCA) (2014): Informe núm. 06/2014, de 11 de septiembre.

DE LA ENCARNACIÓN, A. M. a (2016): "El alojamiento colaborativo: viviendas de uso turístico y plataformas virtuales", en Revista de Estudios de la Administración Local y Autonómica (REALA), nueva época, núm. 5, enero-junio, págs. 30-55. DOI: http://dx.doi.org/10.24965/reala.v0i5.10350.

DOMÉNECH PASCUAL, G. (2018): "La regulación autonómica y local de las viviendas de uso turístico", en Anuario de Derecho Municipal 2017, núm. 11, págs. 43-73.

DUATIS, J., BUHIGAS, M. y CRUZ, H. (2016): Impacto del alquiler vacacional en el marco del alquiler residencial de Barcelona, Gerencia de Empresa y Turismo del Excmo. Ayuntamiento de Barcelona/Duatis Arquitectes SLP/Urban Facts, septiembre.

GARNIER, J. P. (2011): "Del derecho a la vivienda al derecho a la ciudad: ¿De qué derechos hablamos... y con qué derecho?", en Biblio 3w: revista bibliográfica de geografía y ciencias sociales, vol. XVI, núm. 909,5 de febrero. Disponible en: $h t t p: / / w w w . u b . e d u / g e o c r i t / b 3 w-909 . h t m$.

GONZÁLEZ JIMÉNEZ, P. M. (2017): "La oferta de viviendas de uso turístico a través de plataformas colaborativas: reflexiones desde el derecho de la competencia desleal”, en Revista de Estudios Europeos, núm. 70, juliodiciembre, págs. 111-126.

HERRERO SUÁREZ, C. (2017): "Las viviendas de uso turístico: ¿El enemigo a abatir? Reflexiones sobre la normativa autonómica en materia de alojamientos turísticos”, en Revista de Estudios Europeos, núm. 70, julio-diciembre, págs. 147-158.

LANTIGUA, I. F. (2018): "El Ayuntamiento de Madrid ilegalizará el 95\% de las viviendas turísticas del centro", en El

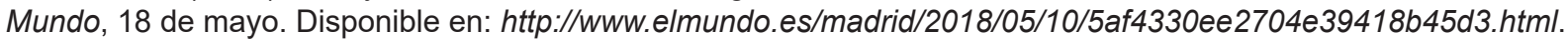

LEFEBVRE, H. (1968): Le droit à la ville, París: Antrophos.

MIRALLES MARUGÁN, P., VILLAR LAMA, A. (2016): "Las viviendas de uso turístico: un análisis del conflicto", en International Journal of World of Tourism, vol. 3, núm. 6, págs. 22-36.

PAREJO ALFONSO, L. J. (2015): "Urbanismo temporal, derecho a la ciudad y marco estatal de las políticas urbanas", en Práctica urbanística, núm. 136, págs. 6-16.

ROCA FERNÁNDEZ-CASTANYS, M. ${ }^{a}$ L. (2017): “¿Matando a la gallina de los huevos de oro?: Algunos apuntes sobre la nueva regulación de las viviendas de uso turístico (especial referencia al caso andaluz)”, en Revista Internacional de Derecho del Turismo (RIDETUR), vol. 1, núm. 2, págs. 1-23. DOI: https://doi.org/10.21071/ridetur.v1i2.10210.

RODRÍGUEZ FONT, M. (2017): "Barreras regulatorias a la economía colaborativa y las nuevas vías de impugnación de normas: el caso de las viviendas de uso turístico", en Revista Española de Derecho Administrativo, núm. 181, enero-marzo, págs. 409-444.

ROMÁN MÁRQUEZ, A. (2018): "Las técnicas de intervención administrativa: autorización, concesión, declaración responsable y comunicación”, en GIFREU FONT, J. (dir.): Litigación Administrativa, págs. 523-557. Valencia: Tirant Lo Blanch. 
REALA. Nueva Época - N.10, Octubre 2018 - ISSN: 1989-8975 - DOI: 10.24965/reala.v0i10.10566 - [Págs. 22-39]

Planificación urbanística del turismo: la regulación de las viviendas de uso turístico en Madrid y Barcelona

Alejandro Román Márquez

ROMÁN SÁNCHEZ, I., PAVLOVA, N., NIETO GONZÁLEZ, J. L. y BONILLO MUÑOZ, D. (2017): "La legislación sobre los apartamentos turísticos y viviendas de uso turístico en España, comparativa por Comunidades Autónomas", en International Journal of Scientific Management and Tourism, vol. 3, núm. 4, págs. 397-417.

SOCIAS CAMACHO, J. M. ${ }^{a}$ (2017): "Un problema actual de la vivienda turística: uso residencial vs uso turístico", en Revista de Derecho Urbanístico y Medio Ambiente, núm. 317, noviembre, págs. 17-47.

SOCIAS CAMACHO, J. M. a (2018): "Estado regulador y alojamiento colaborativo. El régimen de la intervención pública limitadora de la prestación del servicio”, en Revista de Administración Pública, núm. 205, págs. 131-170. DOI: $h$ ttps://doi.org/10.18042/cepc/rap.205.04.

VV.AA (2007): Manual sobre la Transposición de la Directiva de Servicios, Oficina de Publicaciones Oficiales de las Comunidades Europeas.

VV.AA (2017): Manual Operativo del PEUAT, Dirección de Servicios y Licencias, Gerencia de Ecología Urbana, Excmo. Ayuntamiento de Barcelona.

VV.AA (2018a): Informe inmobiliario. Actualidad y perspectivas 2018, Forcadell/Universidad de Barcelona.

VV.AA (2018b): Hotel Price Radar, HRS Global Hotel Solutions. 